\title{
Research and Practice on Teaching Reform of Innovative Applied Talents
}

\author{
Cao Guangming \\ Weifang University \\ Weifang, Shandong Province, 261061
}

\begin{abstract}
This paper expounds the research and practice on teaching reform in view of innovative applied talent training for engineering specialty of local colleges, personnel training specifications and general requirements, teaching content and curriculum system, modes of talent training and teaching as well as specific operation measures.
\end{abstract}

Keywords-Innovative applied talent; Local colleges; Engineering specialty; Teaching reform

\section{INTRODUCTION}

The innovative talent training is the requirement of the era development and the historic mission which must be undertaken by higher education. Although the importance and urgency of the innovative applied talent training has been recognized by the local applied universities and colleges currently and some talent training methods and approaches have also been proposed, the mechanisms and environment conducive to the growth of innovative applied talents have not been formed yet. From the perspective of students, due to the influence of traditional exam-oriented education, the passive learning has become inertia and the concept of autonomous learning and dynamic learning has not formed yet.

Therefore, it is of great significance to the analysis on the quality characteristics which should be equipped by the innovative applied talents, the construction of the corresponding educational mechanisms, the creation of the growth environment conducive to the growth, the achievement of the talent training orientation and goal of the local applied universities and colleges, and the provision of more senior special talents with innovative spirit and innovative ability to the society.

\section{ClEAR THE SPECIFICATIONS AND GENERAL REQUIREMENTS OF TALENT TRAINING}

The innovative applied talents must have a good innovative spirit and practical ability, and simultaneously can be proficient in mastering the knowledge and ability of the specialty and engage in the design, manufacturing, scientific and technological research and development, application research, operation management, business sales and other aspects in the first social production line. Therefore, the professional setting is mainly industry-oriented, and the knowledge structure is complex, interdisciplinary and advanced certainly; The teaching contents do not emphasize the systematicness and completeness of the subject knowledge system [1], but take "enough to use" as the principle, which cannot only meet job requirements, but also have the capacity for sustainable development; In terms of ability training, it focuses on technological innovation and emphasizes the innovative application of existing knowledge; In terms of talent training orientation, the training of the senior professionals in various industries is taken as the goal, and it focuses on the training of the comprehensive qualities such as language expression, teamwork, organizational coordination, cross-cultural communication as well as the social adaptability [1]. Based on the above basic ideas, the overall requirements for the training of innovative applied talents with "wide basis, multi-dimension, practice stressing, application highlighting, incentive innovation and comprehensive development" have been identified.

\section{BuILD THE TEACHING CONTENTS AND CURRICUluM SYSTEM THAT ADAPTS TO TALENT TRAINING}

The scientific setting of the courses and the construction of the reasonable teaching contents and curriculum system is the first step in training innovative applied talents. In terms of overall design, it can optimize the basic platform of "platform + module, implement the direction package training, moderately compress the theory class hour, provide students with more independent study time, guide the students' independent development, and create good environment for individualized talent training. The scheme embodies the "student-centered" education and teaching philosophy and the overall requirement of talent training.

The new curriculum system has the following features: (1) establish a general education teaching platform, improve the credit requirements for selective elective courses in general education, expand the students' knowledge, put focus on training students' scientific and humanistic qualities, and contribute to the overall quality formation of the students. (2) Build a basic teaching platform for the major discipline specialty, broaden and consolidate the foundations of the major specialty of the students, and lay a foundation for follow-up direction-oriented training. (3) Set up a number of professional direction course modules, allow students to freely choose according to their interests and employment orientations, achieve the classified teaching and flexible training; Set up the professional elective course modules, provide more professional optional courses for students' free choosing, 
enrich the knowledge base and rationalize its knowledge structure. (4) Set up the professional practice teaching modules, appropriately increase the proportion of practical teaching, optimize the setting and arrangement of practical teaching, make the theory and practice "under parallel in double-line" and close combination, and make the practical teaching and innovative education throughout the entire process of talent training [2].

\section{BUILD THE OPERATION MODE THAT ADAPTS TO TALENT TRAINING}

In order to train the innovative applied talents, the "three combinations, one highlight" talent training operation mode with obvious applied undergraduate course characteristics has been identified with the talent training concept of "taking quality as the root, application as the foundation, ability as the priority and innovation as the soul" [3].

The first is "combination of production, education and research". The operating mechanism that closely combines production, education, and research is established, the solid practical teaching base inside and outside schools are established, and the school running is opened. The education mode of production, education, and research "combines the classroom teaching which puts emphasis on knowledge transfer with the production process and technological innovation during which the practical experience and practical skills can be directly acquired"'4], which provides an ideal platform for the training of students' innovative practical ability.

The second is "the combination of theory and practice". Through many years of practice, a practical teaching system conducive to the training of innovative applied talents has been built, which makes it become paralleled with theoretical teaching [5], can ensure a close combination of theoretical teaching and practical teaching, realize theory $\rightarrow$ practice $\rightarrow$ retheory $\rightarrow$ re-practice, practice in learning, learning in the practice, and avoid the disconnection between theory and practice.

The third is "the combination of in-class and extra-class". With the harmonious development of the overall quality of people as the objective, the extra-class training system construction has been vigorously carried out including "extraclass reading activities (academic lectures, various interest groups, social investigation and practice, and colorful cultural and sports activities, and the extra-class guidance learning mode has been built, which can train the students' scientific and humanistic qualities, therefore, a new system of quality education has been formed [5].

"One highlight" means to highlight the training of the students' professional practice ability and the overall quality with the innovation spirit as the core [5].

\section{BUILD THE CURRICULUM TEACHING MODE THAT ADAPTS TO TALENT TRAINING}

The traditional curriculum teaching mode is teachercentered, under which the students will be in a passive position and become inert, don't love, like and even dare to ask questions, and the students' divergent thinking and reverse thinking will be constrained, which are not conducive to the training of the students' innovation spirit and innovative ability. Therefore, the new curriculum teaching mode should be guided by the "teacher-led and student-centered" education ideology and supported by modern information network technology so that the teachers can step out of the teaching center and the students can be liberated from passive learning and carry out autonomous learning and dynamic learning.

In terms of teaching methods, for highly theoretical contents, the teachers' teaching should prevail so as to give full play to the teachers' knowledge, experience and other advantages, use their own innovative thinking and innovative spirit to infect and guide the students and encourage the students to learn and explore with a critical look and innovative spirit. The "inspiring" and "interactive" teaching methods are adopted to inspire and prompt the students to actively think about and answer questions through the methods such as question assuming, judgment delaying and discussion, so as to draw the students' ideas into the teachers' lectures and to achieve the agreement and integration of the teachers and students and the interaction and resonance in the thinking. For contents with strong applicability, the "study-guiding" teaching [3] is adopted, and the teaching methods such as question method, discussion method, case method, special case study, comprehensive design, comprehensive experiment and open large assignment are adopted, the students are required to participate in teaching activities as much as possible to guide the students to actively think, analyze and solve problems, so as to achieve the purpose of teacher-student interaction and ful mobilization of the students' enthusiasm for learning [6].

In terms of teaching methods, the teachers can use multimedia teaching courseware, create inspiring and guiding type teaching scenarios and mobilize students' positive thinking [3] and make the abstract and complicated teaching contents become more concrete, which is conductive to inspiring students' interest in learning and curiosity, training their selflearning abilities and improving the teaching effectiveness. With the modern teaching methods, the teachers can carry out the sufficient teaching design before class, provide extensive learning materials and design thinking questions, etc. Some of the contents in the original which cannot be embodied in the class can also be fully displayed with the help of multimedia devices. Even the actual production process, scientific experiment, and engineering practice can be introduced into the class through multimedia devices, thereby making the closed classes become open and achieving the combination of teaching, scientific research and production, which is conducive to training the students' innovative spirit [6].

In terms of the organization of teaching, attention is paid to the construction of two classes. One is a traditional class in the classroom where the teachers dominate the entire teaching process, they are the instructors of the teaching contents and 
the organizers of the teaching; the first is the online class, and the teacher is the provider of teaching resources, the constructor of the teaching environment and the promoter of the student learning. The teachers can carry out the corresponding "learning environment construction" and create a brand new information-based teaching environment according to the students' "self-learning strategy" through the integration of information technology and curriculum, this environment can support the situation creation, thinking inspiring, self-learning, problem research, information acquisition, resource sharing, multi-interaction, collaborative communication and other teaching and learning activities and achieve a kind of new curriculum teaching mode characterized by "autonomy, exploration and cooperation" that can both play a leading role of the teachers and fully embodying the student's dominant position. [7], so that the students' initiative, enthusiasm, and creativity can be fully utilized [6].

\section{SPECIFIC MEASURES FOR TALENT TRAINING}

\section{A. Update Concepts}

To carry out teaching reforms, the concept of education and teaching must be firstly updated, and the major discussion on the concepts of education must be carried out so that everyone can reach a consensus on ideology and be consistent in action. Since teaching is a matter related to both teachers and students, thus, the new teaching concept must not only be mastered by the teachers but also be mastered by the students. It is necessary to carry out educational activities such as the reform of learning methods among students, which can lay the foundation for the follow-up study as the first compulsory course for undergraduates [6].

\section{B. Building a Teacher Team with Innovative Spirit and Innovative Ability}

A team of teachers with innovative spirit and innovative ability is an important guarantee for training innovative applied talents. A scientific and reasonable teacher assessment mechanism should be established, the teachers should be encouraged to carry out the teaching reforms, the curriculum teaching mode should be innovate and the students' interest and enthusiasm for learning innovation should be stimulated and mobilized. The cooperation between schools and enterprises and between localities and schools should be strengthened, and the teachers should be encouraged to go deep into the front lines of enterprises, research institutes and engineering practices, to understand and master the latest scientific research trends, scientific research achievements and academic frontiers and to update the teaching contents in a timely manner. Simultaneously, the well-known experts, researchers and senior management personnel should be employed from the industry to give lectures in schools and bring the latest technology frontiers and key technical problems to the class so as to jointly train the innovative applied talents [8].

\section{Build a Solid Practical Teaching Base}

The practical teaching base is the basic platform for training the students' innovative practice ability. Weifang is a dynamic industrial city with a good engineering environment. Through cooperation with the enterprises such as Goertek Co., Ltd., Weichai, Foton Lovol International Heavy Industry Co., Ltd., the mechanisms and modes for training the applied talents have been explored and established such as "course replacement", "order type training", "in-post practice" and "graduation practice "dual-mentor system". In terms of the urgent talents in enterprises, the teaching plan should be actively adjusted and the "order-style" training should be implemented; In terms of the professional practice, graduation practice and other aspects, the "dual-mentor" system should be implemented to achieve the purpose of school-enterprise cooperation in educating people; The production subject of the enterprise should be introduced into the class so as to improve the students' innovative practical ability through course design, design competition and other forms. All of the graduates at the mechanism major in the nearly two years have received enterprise engineering technology training in Weichai and carried out the graduation practice. Through cooperation with Foton Lovol International Heavy Industry Co., Ltd., the "quasiemployee graduates" have been recruited for "order type" training. Through cooperation with Goertek Co., Ltd., the orientation courses of Goertek Co., Ltd. has been set and the training courses of Goertek Co., Ltd. has been established, which can train the necessary talents for the enterprise. Through the above-mentioned cooperation, the integration of practice, training and post has been realized, which has not only trained the students' engineering practice ability, but also solved the students' employment problems, the enterprises have employed the urgent talents and a win-win cooperation has been achieved.

\section{Improve Innovative Education Mechanism}

In order to train the students' innovative practice abilities, the campus practice teaching base has been opened, the virtual teaching classroom for innovative practice has been set up, the student innovation department has been formed, the innovative tour system has been implemented, and the relatively perfect education mechanism for stimulating innovative practice has been formed which returns the innovation practice education of the students to the correct track, a virtuous circle has been formed, and outstanding achievements have been achieved in various discipline competitions. In the past five years, the students have applied for 15 national utility model patents, there have been 140 teams participating in various national and provincial competitions for undergraduate subjects and a total of 123 national and provincial awards and above have been awarded, including 7 national awards. In the Electromechanical Product Innovation Design Contest of Shandong Province, they won the Outstanding Organization Unit Award and won the Innovation Practice Teaching Achievement Award of Shandong Province. 


\section{E. Implement Project Tutor System}

In order to train the personalized innovative talents and implement the project tutor system among undergraduates, firstly, the academic guidance should be provided for students and the students should be guided to reasonably select the professional development directions based on their own interest, hobby, specialty, intelligence and ability development situations, and the guidance in course selection, learning method, career design, etc. should be carried out. Secondly, the innovative project tour resource library should be established, the classified guidance should be carried out in the innovative practice of the students, the special education for innovative practice should be organized, the students should be guided to actively participate in social practice and scientific and technological innovation activities, the students' innovative spirit and practical ability should be trained, and the coordinated development of the students' knowledge, ability and quality should be promoted.

\section{F. Build the Appraisal and Evaluation System That Adapts To the Talent Cultivation}

The reform of appraisal and evaluation mechanism is an important part of the entire reform. There are three main points: Firstly, it combines formative appraisal with summative appraisal, puts focus on process appraisal, and includes the students' usual homework, stage test, class appraisal and regular experiment into the appraisal in appropriate proportions to fully reflect students' learning status. Secondly, the appraisal methods should be diverse as much as possible, the oral and written tests, open and closed book examinations, design, production, papers, research reports, etc. should be taken according to different requirements of the curriculum, which is conducive to carrying out the effective appraisal and evaluation on the students' innovative practice ability. Thirdly, the network appraisal mode should be established. The online teaching platform should be used to establish the online testing system so as to make the process appraisal become relatively easy and the appraisal results become more objective and fair.

\section{CONCLUSIONS}

After five years since the above-mentioned reforms were begun in 2013, the positive results have been achieved. The innovative awareness, innovative ability and engineering practice ability of three undergraduate students (mechanical design and manufacturing and its automation, vehicle engineering and industrial design) have significantly improved. The follow-up survey feedback of the graduates shows the satisfaction rate of the employer with the students' professional skill application ability and comprehensive ability is $100 \%$, and the postgraduate qualifying examination rate of the students is stabilized at about $20 \%$, the employment rate is more than $97 \%$, and employment quality and enrollment rate of the students are getting better and better, and a good social reputation has been won. In the next step, the relevant reform measures will be improved in order to strive for greater progress in the talent training quality.

\section{REFERENCES}

[1] Cai Zhongbing. Education Teaching Reform Strategy Based on Innovative Application-oriented Talent Training [J]. Modern Enterprise Education, 2010(04):176-177. (In Chinese)

[2] Feng Binlu, Liu Fenglou. On Diverse Tendency of New Local University Students and Its Countermeasures [J], Shandong Higher Education, 2015,3(12):5-11+2. (In Chinese)

[3] Yu Qicai, Zhang Jjunping, Zhang Ling. Airong Liu. Innovation Applied Talents: Training target positioning of Local Key Construction University [J], China High Education, 2010, (22), P24-29. (In Chinese)

[4] Zheng Dafeng. Practice of University-industry Collaboration in The Undergraduate Course Teaching [J], Guangzhou Chemicals,2010,(8) P302-303. (In Chinese)

[5] Material forming characteristic professional declaration material_text, Internet documentation resources(http://wenku.baidu.c), 2017-2-11.(In Chinese)

[6] Cao Guangming. Research of Reforming the Teaching Modes for University Courses Under Information-based Condition [J], Journal of Weifang University, 2009,(6), P139-141. (In Chinese)

[7] He Kehang. Education Infomatization and University Teaching Reform [J], Journal of China University Teaching, 2007, (10), P64-71 (In Chinese)

[8] NingBin-President of Beijing jiaotong university. Innovative talent training should grasp three points of focus, 2010-01-28. (In Chinese) 